The magnitude of the hearing losses in these ears seems too great to be solely accounted for by the modest atrophic changes in the hair cells. A more detailed population count of the hair cells and nerve endings is in progress and may be revealing. At this time we doubt that the changes are sufficient to account for the hearing losses.

Atrophy of the stria vascularis has been shown to be a common cause for deafness of aging. In the present study, strial atrophy was found in both ears, the left more than the right. However, the spatial distribution and severity seems to be inadequate to account for the hearing losses, particularly in the right ear. The thick hyperplastic strial epithelium seen in the left ear may be a compensatory activity for the loss of adjacent atrophic stria.

The only positive correlaticn between morpholo- gical alteration and function is the distension of Reissner's membrane. Possibly this membrane, 'if extend beyond a certain limit, undergoes a loss of some function, such as permeability or sound conduction. One observation is clear, the ear with the more severe hydrops and the greater atrophic change in the sensory and neural structure.

These findings raise the possibility that the hearing loss may be contributed to by biochemical alterations in endolymph or perilymph or cytochemical alterations in the hair cellr and/or nervous tissue. The observations are compatible with the thesis that the cochlear changes are secondary to volumetric and qualitative changes in endolymph, similar to those occurring in experimental endolymphatic hydrops following surgical obstruction of the endolymphatic duct.

\title{
蝸牛内直流電位の消長とマイクロフォン電位との相関性
}

\section{志多亭 (大阪鉄道病院)}

有毛細胞起源である Cochlear Microphonics (以下 CM) 汢 Summating Potential (以下SP) とともに現段 階では一応聴覚末梢感覚装置の受容電位であると考えら れ，内耳におけるエネルギ一変換を示寸電気的表現とし て理解されている。この上うな有毛細胞の電気的な activity を決定的に支えているのは Reticular Lager を境と して Endocochlear DC Poteutial (以下 EP) とコルチ 器内負電位とによつて構成される $180 \mathrm{mV} に$ によぶ直流 電位勾配であり，この直流電位差の減少は有毛細胞自体 に障害がなくても即 $\mathrm{CM}$ の減少となつて現われる。し かもこの直流電位差を構成する両電位の中聴器毒中毒時 等の特殊な場合を除いて各種の条件負荷に対してもコル 千器紐胞内負電位は抵抗性が強く，その值が安定であ り，この電位差の值を変動させる主因はほとんどの場合 EP の側にある。したがって EP の変動はそのまま直流 電位勾配の変動として $\mathrm{CM}$ にこれと一致した変動を強 制することになる訳であるが，モルモットを実験動物と した場合，ある条件下では EP と CM が必ずしも一致 した変動を示さぬ事実が発見された。この不一致の根源
を検索することは EP の発生起源の追究に連なると同 時に CM 発生にあたつての有毛細胞の直流電位勾配利 用能の背景を知るための手段ともなる。この意味でまず 螖牛中央階の Polarization 種々のレベルに変換して, これに伴なら $\mathrm{CM}$ の変化を検討した。このために尖端 $1 \sim 2 \mu$ の硝子毛細管電極を 2 本, 螖牛基礎回転中央階に 挿入し， 1 本は誘導電極とし, 他の 1 本は別に鼓室階に 扱入した同様の毛細管電極ととむに通電電極とした．電 流そのものによる有毛細胞障害を避けるために通電電極 間には更に 3 5M $\Omega$ の抵抗を入れて通電電流は最大で も $15 \mu \mathrm{A}$ をこえないように留意した，正常状態で EPが $80 \mathrm{mV}$ あることを確認した上で通電により $\mathrm{EP}$ を増减 し， EP とCM との相関性を観察した場合， EP の減少 すなわち中央階の電圧低下時には $\mathrm{CM}$ はこれと一致す る減少を示すが，EP の増大すなわち中央階の電圧上昇 時には $\mathrm{CM}$ は必ずしもこれと一致した増大を示さない ことが分つた，すなわち EP が 90〜110mV に達する までは $\mathrm{CM}$ はこの中央階電圧増大分に応じた增大を 示すが，次第にその増大度は小となり， $\mathrm{EP} か ゙$ 120 130 
$\mathrm{mV}$ 以上となれば $\mathrm{CM}$ は逆に必ず減少を示すことが樭 察された。このように EP の電圧が十分であつても が逆に減少傾向を示す事実は Anoxia の回復期および前 下小媨動脈の長時間閉塞による local anoxia の回復期 にもみられる.すなわち anoxia を解除して EP が既 に元のレベルに戻るかあるいは overshoot のある時期 に一旦増大した $\mathrm{CM}$ が再び比較的急速に減少する現象 が観察されるが, これらの $\mathrm{EP} と \mathrm{CM}$ の不一致はすべて 有毛細胞自体に何等かの機能障害が起つたものとして十 分説明可能である。

一方利尿剂の一程でめる Furosemide の大量静注 (30 $\mathrm{mg} / \mathrm{kg}$ )を行うと $\mathrm{EP}$ が極めて急速に減少し極性逆転を きたした負の $\mathrm{EP}$ となり，-20〜-40mV の最低值に達 した後，再び比較的緩徐に回復を示す事実が知られてい る.この場合 $\mathrm{EP}$ と $\mathrm{CM}$ の同時記録を行らと $\mathrm{EP} の$ 急 激な低下時期には $\mathrm{CM}$ む完全にこれと一致した急速な 滅少をきたして最低値に達するが，この回復時期におい て EP と CM とが前述の場合とは逆の関倸において不 一致の変動パターンを示すことが明らかとなってきた. すなかち $\mathrm{EP}$ の回復がなお極めて微小であり，そのレ バルが負から漸く $\mathrm{omV}$ 内外まで回復した時期において 既にCM は元のレぶルの 80〜100\% 場合によつては極 端な overshoot さえ示す事実が検出された．換言すれ ばこれは $\mathrm{CM}$ 発生のための電源電圧である $\mathrm{EP}$ がなお 極めて小さいにかかわらず， $\mathrm{CM}$ が十分に発生し得る場 合のあることを示すもので，ある特定条件下では CMの 発生には $+80 \mathrm{mV}$ におよぶ巨大 $\mathrm{EP}$ は不要であること を意味するものであると考えられる．EP の值が正常值 を保つていても $\mathrm{CM}$ が極めて小さいか，又注全くその 発生をみないことは聴器毒投与あるいは強大音曝露時等 の条件下で屢々現在までに確認されてきた事害であり， 前述の anoxia あるいは local anoxia 回復期の EP, $\mathrm{CM}$ 不一致の場合と同様に有毛細胞障害の存在によつて 簡単に説明できる現象であるが，EP が著しく減少した 值にある時に CM が何等の低下なく発生することは有 毛細胞が健全である限り CM が常に電源電圧としてEP のと一致した変動を示すものと考えてきた現在までの概 念㲹反する事実である.

Furosemide 投与後にみられるこのよらな EP と CM の変動の解離現象の発見は末梢聴喾装置におけるエネル ギー変換機構を更に詳細に知り得るための一つの系口と なるものと思われ，この $\mathrm{EP}, \mathrm{CM}$ の動態不一致の根源 を明らかにすることは惹いては臨床的にある種の難聴群
の発生原因の究明あるいは治療に寄与する可能性が大き い課題である. 前述の cochlear polarization の変撸実 験手技を用いて Furosemide 投与後の EP 激減期に蝸 牛中央階の電圧を Furosemide 投与前のレベルである $80 \mathrm{mV}$ に一定に clamp して, CM の変動の有無を検討 したが，電源電圧としての中央階の Polaization が一定 正常值に維持されているにかかわらず，Furosemide 投 与後 $1 \sim 2$ 分間は $\mathrm{CM}$ ほ微小ながら減少を示し最低值 として Furosemide 投与前の $80 \sim 85 \%$ に達した後, EP の回復期にやや先がけて回復する傾向を示した. Furosemide 投与後の EP 回復期だけでなく，投与直後 のEP 減少期においても voltage clamp に上る中央階 の電圧一定化に完全には一致しない $\mathrm{CM}$ の変動がみら れたことは Furosemide 投与後の EP, CM の不一致の 背景に Furosemide 自体の蝸牛における萁理作用の特殊 性を考えなければならない，一般に Furosemide の利 尿作用機序は尿細管上皮における Na-K の交換阻止に 基づく $\mathrm{Na}$ の再吸收阻止にあると言われるが，一方 $\mathrm{EP}$ の発生源は最近では血管帯における Na-KATPase system の functioning であり,この Na-K exchange pump の働きが electrogenic pump として EP を発生すると する考え方が支配的になりつつある. EP 発生に関して のこの考え方が正しいとすれば Furosemide の投与によ る EP の急激な減少は血管帯における Na-K exchange pump の㗢きが Furosemide の投与により一挙に停止し た結果として理解される. C. Smith により報告された 内リンパの外リンパに対する異常なまでの高カリウムと 低ナトリウムのイオン濃度はこの Na-K exchange pump active の働きによる血管帯から中央階えのKイオンの active transport と中央階からの Na の汲み出しにより 維持されていると考えることができる，とすれば Furosemide 投与による血管帯におけるこの pump の停止が 内リンパのイオン組成に変化を括よぼし，その変化が現 状では解析不能の $\mathrm{EP}, \mathrm{CM}$ の不一致パターンを招来 する原因である可能性を考えねばならないこの意味 に抬いては $\mathrm{K}, \mathrm{Na}, \mathrm{Cl}$ の各イオン濃度の変動について の検討が要求されるが，今回はイオン濃度のみに焦点 を絞つてその変動様相を追究することにした，中央階 の $\mathrm{K}$ イオン濃度測定にあたつては potassicem ion exchange liquid 尖端 $100 \sim 200 \mu$ の長さに封入した 0.5 $\mathrm{Mol} \mathrm{KCl}$ の硙子毛細管電極を作成して $\mathrm{K}^{+}$電極とし, これを中央階に挿入後 Electrometer (keithley-160C) に接続し, 中央階の $\mathrm{K}^{+}$イオン濃度の変動を追跡した。 
一般に $\mathrm{K}^{+}$電極法によるKイオン濃度として読みとら れる Electrometer 上の読みは附図の如き 経験的理論式 によつて与えられるもので $\mathrm{K}+\mathrm{i}$ (electrode inside) ?と Ke (electrode outsicle) とのKイオン濃度の対数比の一 定恒数倍の值として表現される。この $\mathrm{K}^{+}$電極の使用 に当つては予好用意された 5 段階の既知濃度の $\mathrm{KCl}$ 溶 液中に電極尖端を浸し, Electrometer 上の読みで電極 の感度較正を行い, $\mathrm{Ki}^{+}$と $\mathrm{Ke}^{+}$との対数比が理論值に 完全に一致するかあるいはほぼこれに等しいもののみを 実験に使用した。 なお，実際に蝸牛中央階に $\mathrm{K}^{+}$- 電極 を㨀入した場合 Electrometer には上の電圧值はKイオ ン浱度による activity に更に中央階内の直流電極 とし ての EP がこれに加わつたものとなるため，この $\mathrm{K}^{+}$ 電極とは別に更に今 1 本の誘導電極を中央階に同時に楿 入し,これによつて測定される EP のみの值を常に差し 引きすることによつて $\mathrm{K}^{+}$-イオン濃度を求める必要が ある.このよらにして測定された内リンパのKイオン濃 度は Furosemide 投与後急速に減少し $1 \sim 1.5$ 分で最低 值に達し, $2 \sim 3$ 分では既に回復を示し $7 \sim 10$ 分では Furosemide 投与前を淩ぐ最高值に達した以 後次第に元

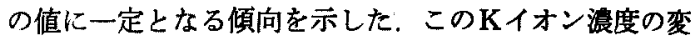
動パターンは EP のそれよりもむしろ CM の変動パタ ーンとよく似ており，EP のレベルが極めて低いにかか わらず，CMが正常もしくはそれ以上のレベルに発生す ることの原因にKイオン濃度の変化分が主役を演してい る可能性を思わせるものがある，CM 発生のための電源 電圧である中央階の $\mathrm{EP}$ が下降して有毛細胞でのエネ ルギー変換能が危機状態となると何等かの醭素活性が賦 活され内リンパ中のKイオン濃度の僅かの増加を極めて 有効に利用し，CM 発生率を著しく増大するのか子知れ 有ない、いずれにせよこれらはなお推測の域をでないで 毛細胞が健全である限り螖牛におけるエネルギー変換機 構の維持に注第 1 次的に電源電圧としての $\mathrm{EP}$ の存在 が必要であるが，EP と内リンパ液中の $\mathrm{K}^{+}$イオン灙度 が比較的解離した変動を示した場合 $\mathrm{CM}$ が $\mathrm{EP}$ よりを むしろ $\mathrm{K}^{+}$イオン蕽度の動きに伴なつて変動する傾向 が明らかになったことは興味梁、知見である。

最後に本研究遂行に協力された九大, 朝郎並びに大阪 鉄道病院, 阿部両医学士の労に感謝の意を表する.

(附図)

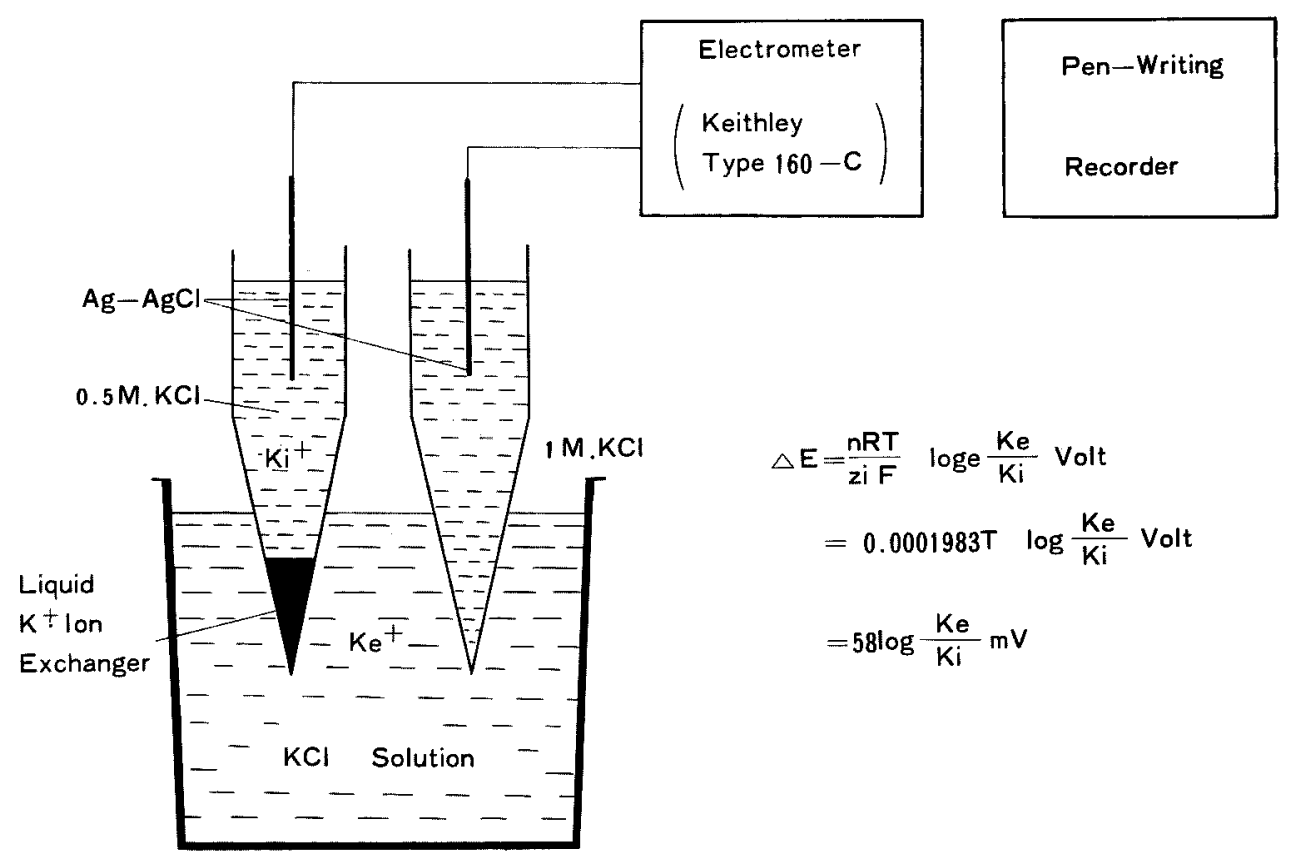

